\title{
Characteristics on Carbonization and Steam Activation of Sewage Sludge
}

\author{
Dong Hyun Jung and Young Nam Chun*
}

BK 21 Team for Hydrogen Production. Department of Environmental Engineering, Chosun University, 375, Dong-gu, Seosuk-dong, Gwangju, Republic of Korea

\begin{abstract}
A number of methods are presented to treat sewage sludge. However, the sludge treated in each treatment process has a problem of heavy metal elution. Currently, the treatment of sewage sludge through carbonization is highlighted to solve such problem. This study carried out research of optimum carbonization and activation condition and analysis of adsorption characteristics in order to treat sewage sludge through carbonization and steam activation and to cycle it as activated carbon. The optimum carbonization and activation conditions were achieved through variable studies and based on iodine adsorptivity. In addition, an analysis was performed with nitrogen adsorption and a SEM to confirm adsorption characteristics and pore development. The results showed that the adsorption capacity of activated derived from sewage (hereinafter referred to as "activated carbon") is improved and porosity is formed through carbonization and steam activation. In particular, micropore is mostly developed by steam activation.
\end{abstract}

Key Words: Sewage sludge, Adsorption characteristic, Carbonization, Steam activation, Activated carbon.

\section{INTRODUCTION}

Among wastes, sewage sludge is currently attracting much attention with respect to its treatment method. This is because the existing treatment methods, i.e. landfill and ocean dumping have been prohibited or restricted. In Korea, landfill is fully prohibited and ocean dumping is being prohibited step-by-step [1]. In this regard, many researchers have studied how to treat sewage sludge in an environmentfriendly method [2-5]. Among the various treatment methods of sewage sludge, the manufacture of adsorbents using sewage sludge is highlighted in terms of environment-friendly treatment and recycling. The manufacture of adsorbents using sewage sludge is performed through carbonization and activation processes. The volumes and weights of solids are decreased by the carbonization and activation processes of sewage sludge, there are few problems of dioxin with reaction under anoxic conditions, and there is no danger of elution, since heavy metals are adsorbed within the pores of manufactured adsorbents [6]. Accordingly, it is expected that the adsorbents manufactured through carbonization and activation will be used as the adsorbents for air and water. On the other hand, it is most important to form the reducing atmosphere in the carbonization and activation processes for manufacturing adsorbents. Carbonization causes the generation of char and gases such as $\mathrm{H}_{2}, \mathrm{CO}, \mathrm{CO}_{2}$, and $\mathrm{CH}_{4}$. Because its inner pores and specific surface area are scanty, the char formed by carbonization can improve adsorbents by adding activation process. In case of chemical activation, different kinds of pore should be developed according to using the kinds of the chemicals, and physical activation is performed by injecting mostly steam or oxidative gases such as $\mathrm{CO}_{2}$ at high temperatures. In this case, pores are formed,

*Address correspondence to this author at the Department of Environmental Engineering, Chosun University, Gwangju, Republic of Korea; Tel./Fax: +82-62-230-7156; E-mail: ynchun@chosun.ac.kr as carbon atoms are removed from char molecules in $\mathrm{CO}$ or $\mathrm{CO}+\mathrm{H}_{2}$ and selective oxidation is performed in the interior of particles [7].

This study attempted to manufacture adsorbents through carbonization and steam activation in terms of environmentfriendly and recycling as well as treatment of sewage sludge, and investigated optimum carbonization and activation conditions and adsorption characteristics. In this regard, the study performed variable studies, changing each influential factor of carbonization and steam activation.

\section{MATERIALS AND METHODOLOGY}

\section{Materials}

The sewage sludge used in this study was dehydrated cake generated from the treatment of domestic sewage from Gwangju City in South Korea. Table 1 shows the results from the outline analysis and element analysis of the dehydrated cake.

\section{Test Experiment Equipment}

Fig. (1) is a simulation test device for carbonization and steam activation used in this study. The device's reactor for carbonization and steam activation, a stainless pipe of $85 \mathrm{~mm}$ and $500 \mathrm{~mm}$ in diameter and length respectively, is heated with the electric furnace (CLF-T1320, CERINHITEC) that enables to control temperature up to $1000{ }^{\circ} \mathrm{C}$. In addition, ceramic distributors were placed in two places at the lower part within the reactor to keep the flow of fluids uniform. Samples were put into the vessel whose lower surface is made of stainless-steel mesh. The continuous measurement of temperature was made possible with the thermocouple (Ktype, O.D.: $6 \mathrm{~mm}$ ) and the data analysis device (Hydra data logger 2625A, FLUKE). A fixed quantity of nitrogen gas was injected at the two places of the lower reactor. In case of 
activation process, steam was provided, with a steam generator installed. The steam generator, a stainless-steel pipe of $17.5 \mathrm{~mm}$ and $350 \mathrm{~mm}$ in diameter and length respectively, has a heating stick inserted whose temperature can be internally kept up to $250{ }^{\circ} \mathrm{C}$. The amount of steam was controlled with the syringe pump (KDS 100, KDScientific, USA).

Table 1. Proximate Analyses and Ultimate Analyses of Dewatered Sludge

\begin{tabular}{|c|c|c|c|}
\hline \multicolumn{3}{|c|}{ Item } & Dewatered Sludge \\
\hline \multirow{3}{*}{$\begin{array}{c}\text { Proximate } \\
\text { analysis } \\
(\mathrm{wt} \%)\end{array}$} & \multicolumn{2}{|c|}{ Moisture } & 79.5 \\
\hline & \multirow{2}{*}{$\begin{array}{l}\text { Organic } \\
\text { compound } \\
\text { contents }\end{array}$} & Wet base & 11.4 \\
\hline & & Dry base & 55.6 \\
\hline \multirow{7}{*}{$\begin{array}{c}\text { Ultimate } \\
\text { analysis } \\
(\mathrm{wt} \%)\end{array}$} & \multicolumn{2}{|c|}{ Ash } & 9.00 \\
\hline & \multicolumn{2}{|c|}{$\mathrm{C}$} & 14.1 \\
\hline & \multicolumn{2}{|c|}{$\mathrm{H}$} & 10.8 \\
\hline & \multicolumn{2}{|c|}{$\mathrm{O}$} & 2.70 \\
\hline & \multicolumn{2}{|c|}{$\mathrm{N}$} & 25.7 \\
\hline & \multicolumn{2}{|c|}{$S$} & 2.68 \\
\hline & \multicolumn{2}{|c|}{ Higher heating value (kcal/kg) } & 3801.1 \\
\hline
\end{tabular}

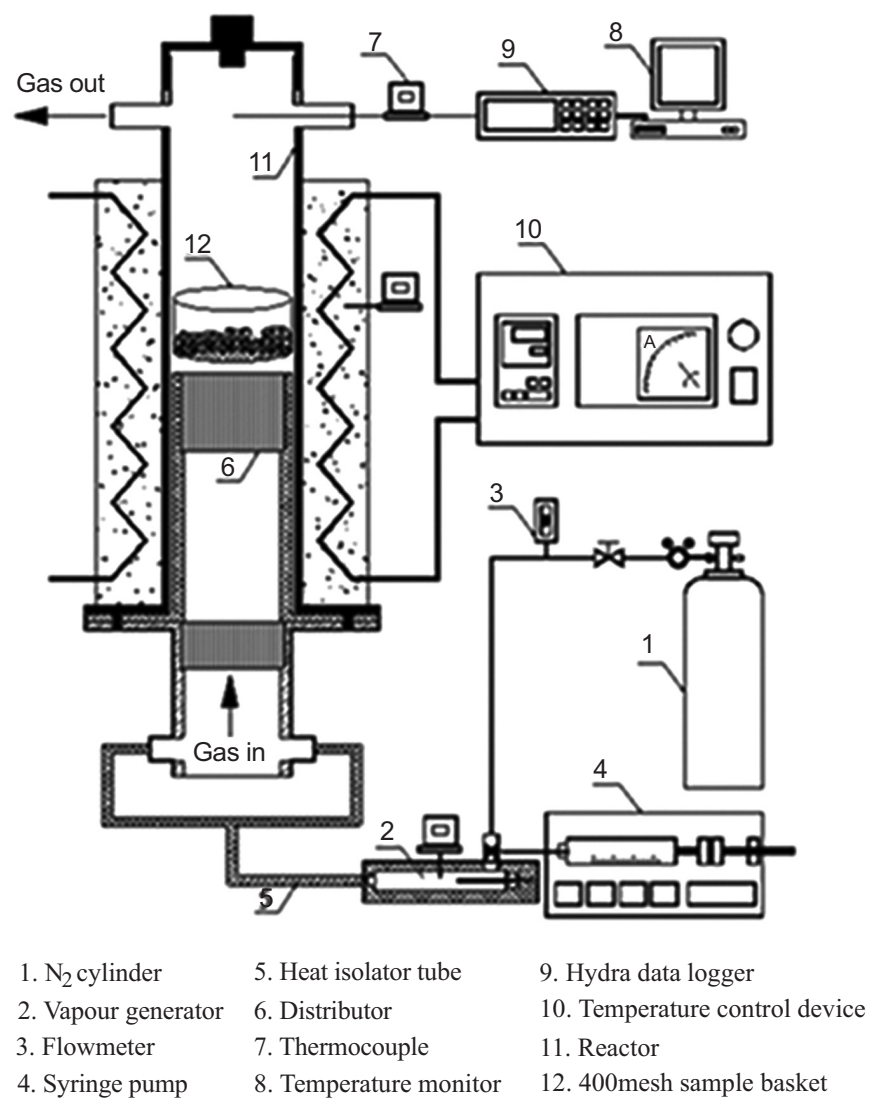

Fig. (1). Schematic of the experimental set up.

\section{Experiment Method}

In this study, it is important to maintain the reducing atmosphere within the reactor in the process of carbonization and steam activation (hereinafter referred to as "activation"). Accordingly, nitrogen gas is continuously injected at a rate of $100 \mathrm{ml} / \mathrm{min}$. Carbonization samples are used after drying the dehydrated cake up to $10 \%$ water content at $105 \sim 110^{\circ} \mathrm{C}$ and sieving it uniformly in particles of $0.25-0.5 \mathrm{~mm}$ sizes. In terms of carbonization process, temperature is raised to 600 ${ }^{\circ} \mathrm{C}$ at a rate of $6.7^{\circ} \mathrm{C} / \mathrm{min}$, and when the temperature is stabilized, samples are put into the reactor and carbonized for 60 minutes. Activation samples are used after neutralizing the carbonized sludge manufactured under optimum conditions by boiling it for 120 minutes with the $3 \mathrm{~N}-\mathrm{HCI}$, acid-washing it and then water-washing it. In terms of the activation process, the temperature is raised to $500{ }^{\circ} \mathrm{C}$ at a rate of 6.7 ${ }^{\circ} \mathrm{C} / \mathrm{min}$. In addition, water is injected into the steam generator at a rate of $30 \mathrm{ml} / \mathrm{min}$ with a syringe pump, gasified steam is provided into the reactor, and when the temperature is stabilized within the reactor, samples are put into the reactor and activated for 60 minutes.

Parametric screening studies were achieved as per carbonization and activation variables, i.e. particle size, dried water content of sludge (hereinafter referred to as "water content"), carbonization temperature, carbonization time, injected water amount, activation temperature, and activation time.

The carbonized sludge and activated carbon manufactured through such process are analyzed with iodine adsorptivity [8], SEM (S-4800, Hitachi, Japan), adsorbent yield [9] and pore characteristics (BET, BJH, HK).

The adsorbent yield should be calculated by eq. (1).

Adsorbent yield $(\%)=\frac{\mathrm{W}_{\mathrm{o}}}{\mathrm{W}_{\mathrm{i}}} \times 100$

$\mathrm{W}_{\mathrm{i}}=$ Initial weight of dried sludge $(\mathrm{wt} \%), \mathrm{W}_{\mathrm{o}}=$ sample weight after activation(wt\%)

The pore characteristics in the specific surface area, mesopore and micropore analyses were calculated as each BET(Brunauer-Emmett-Teller), BJH(Barrett-Joiner-Halenda) and $\mathrm{HK}$ (Horvath-Kawazoe) method using nitrogen adsorption [10-12].

Errors in experiments can arise from observation, reading and test planning. The accuracy of the experiments has to be validated with an error analysis. That was done by using the method of average value and polynomial regression. The average value of data was calculated by results of identical experimental condition. Then each data were analyzed by polynomial regression. For a given data set of $\mathrm{x}$, $\mathrm{y}$ pairs, a polynomial regression of this kind can be generated as the eq. (2). Standard error $\left(S_{y / x}\right)$ was calculated by eq. (3) [13].

$y=a_{0}+a_{1} x+a_{2} x^{2}+a_{3} x^{3}+a_{4} x^{4} \ldots$

$s_{y / x}=\sqrt{\frac{\sum_{i=1}^{n}\left(y_{i}-a_{0}-a_{1} x_{i}-a_{2} x_{i}^{2}\right)^{2}}{n-(m+1)}}$. 


\section{RESULTS}

\section{Carbonization}

\section{I -1. Standard Conditions}

This study set optimum conditions as standard conditions on the basis of iodine adsorptivity by investigating the repetitive variable studies as per the carbonization variables of sewage sludge, and indicated the selected conditions and results in Table 2 . Under the standard conditions, optimum carbonization conditions were set at $0.25-0.5 \mathrm{~mm}, 10 \%, 600$ ${ }^{\circ} \mathrm{C}$, and 60 minutes in particle size, water content, carbonization temperature and carbonization time respectively. In this case, iodine adsorptivity and adsorbent yield turned out to be $161.8 \mathrm{mg} / \mathrm{g}$ and $30.9 \%$ respectively.

Table 2. Standard Conditions and Experimental Data of Carbonized Sludge

\begin{tabular}{|c|c|c|c|}
\hline \multicolumn{3}{|c|}{ Item } & Value \\
\hline \multirow{6}{*}{$\begin{array}{c}\text { Carbonized } \\
\text { sludge }\end{array}$} & \multirow{4}{*}{$\begin{array}{l}\text { Standard } \\
\text { condition }\end{array}$} & Partcle size (mm) & $0.25 \sim 0.5$ \\
\hline & & Content of water (\%) & 10 \\
\hline & & Temperature $\left({ }^{\circ} \mathrm{C}\right)$ & 600 \\
\hline & & Time (min) & 60 \\
\hline & \multirow{2}{*}{$\begin{array}{c}\text { Experimental } \\
\text { data }\end{array}$} & Iodine adsorptivity $(\mathrm{mg} / \mathrm{g})$ & 161.8 \\
\hline & & Adsorbent yield (\%) & 30.9 \\
\hline
\end{tabular}

Fig. (2) shows a comparison of nitrogen adsorption isotherm between the dried sludge of $10 \%$ water content and the carbonized sludge and activated carbon manufactured under the optimum carbonization and activation conditions grasped in this study by the nitrogen isotherm analyzed with the nanoPOROSITY (nanoPOROSITY-XQ, Mirae Co., Ltd. Korea). The adsorption isotherm is classified into 6 types (Types I - VI) [10]. The dried sludge belonged to Type III and had few pores. The carbonized sludge belonged to Type II and showed that the development of pores was found in mesopore and that adsorption capacity was increased to some extent by carbonization process.

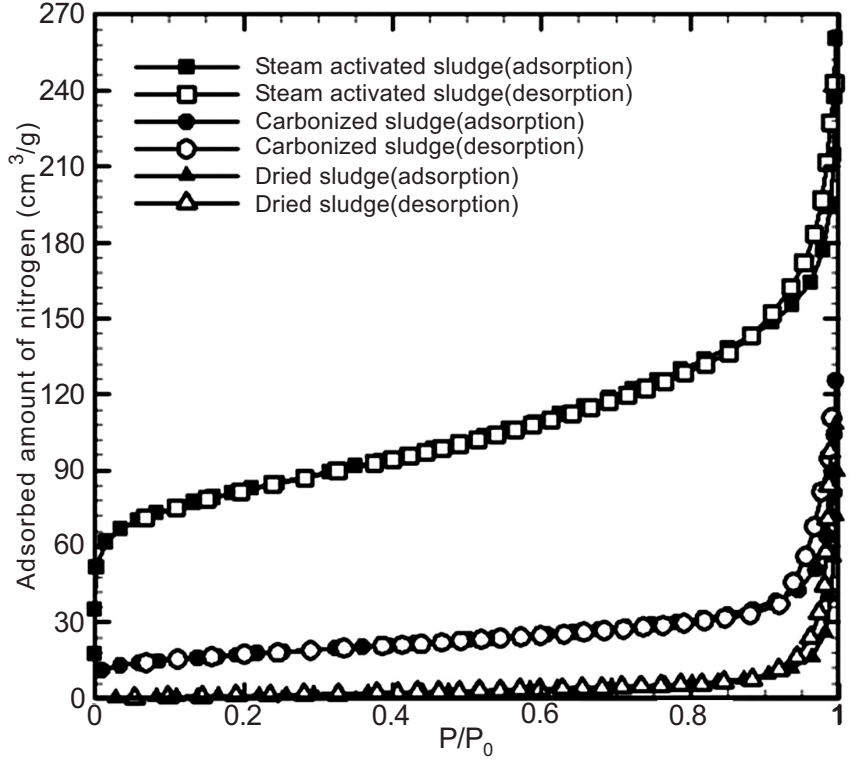

Fig. (2). Adsorption isotherm of nitrogen on dried sludge, carbonized sludge and activated carbon.

Table 3 indicates the specific surface areas by pore sizes for the dried sludge, carbonized sludge and activated carbon manufactured under optimum conditions: the specific surface areas most increased in the BJH(Barrett-Joiner-Halenda) method showing the specific surface areas of mesopore, as seen in the increase from $6.32 \mathrm{~m}^{2} / \mathrm{g}$ of dried sludge to 41.41 $\mathrm{m}^{2} / \mathrm{g}$ of carbonized sludge. At this time, the mean pore diameter of mesopore turned out to be $36.61 \AA$.

Fig. (3) is a result obtained by magnifying pores 5,000 times using a SEM(Scanning Electron Microscope) to grasp the development of pores by the carbonization of sewage sludge. Few pores are found on the surface of the dried sludge in Fig. (3a), but some pores were formed on the carbonized sludge in Fig. (3b). However, iodine adsorptivity and specific surface area were low, and few micropores were found. As a result, carbonization alone made the formation of porosity insufficient.

\section{I -2. Parametric Screening Studies}

Variable studies were performed by changing particle size, water content, carbonization temperature, and carboni-

Table 3. Adsorption Characteristics of Dried Sludge, Carbonized Sludge and Activated Carbon Through Carbonization and Steam Activation

\begin{tabular}{|c|c|c|c|c|c|c|c|}
\hline \multirow{2}{*}{ Item } & \multicolumn{3}{|c|}{ Specific Surface Area $\left(\mathrm{m}^{2} / \mathrm{g}\right)$} & \multicolumn{2}{|c|}{ Pore Volume $\left(\mathrm{cm}^{3} / \mathrm{g}\right)$} & \multicolumn{2}{|c|}{ Mean Pore Size (̊̊) } \\
\hline & BET $^{1)}$ & $\mathbf{H K}^{2)}$ & $\mathbf{B J H}^{3)}$ & HK & BJH & HK & BJH \\
\hline Dried sludge & 6.44 & 0.97 & 6.32 & 0.001 & 0.030 & 16.32 & 94.02 \\
\hline Carbonized sludge & 62.31 & 7.24 & 41.41 & 0.008 & 0.051 & 14.84 & 36.61 \\
\hline
\end{tabular}

${ }^{1)} \mathrm{BET}\left(\right.$ Brunauer-Emmett-Teller) ${ }^{2)} \mathrm{HK}\left(\right.$ Horvath-Kawazoe) ${ }^{3)} \mathrm{BJH}($ Barrett-Joiner-Halenda). 
zation time into $0.25-3 \mathrm{~mm}, 5-20 \%, 400-750{ }^{\circ} \mathrm{C}$, and $30-120$ minutes respectively.
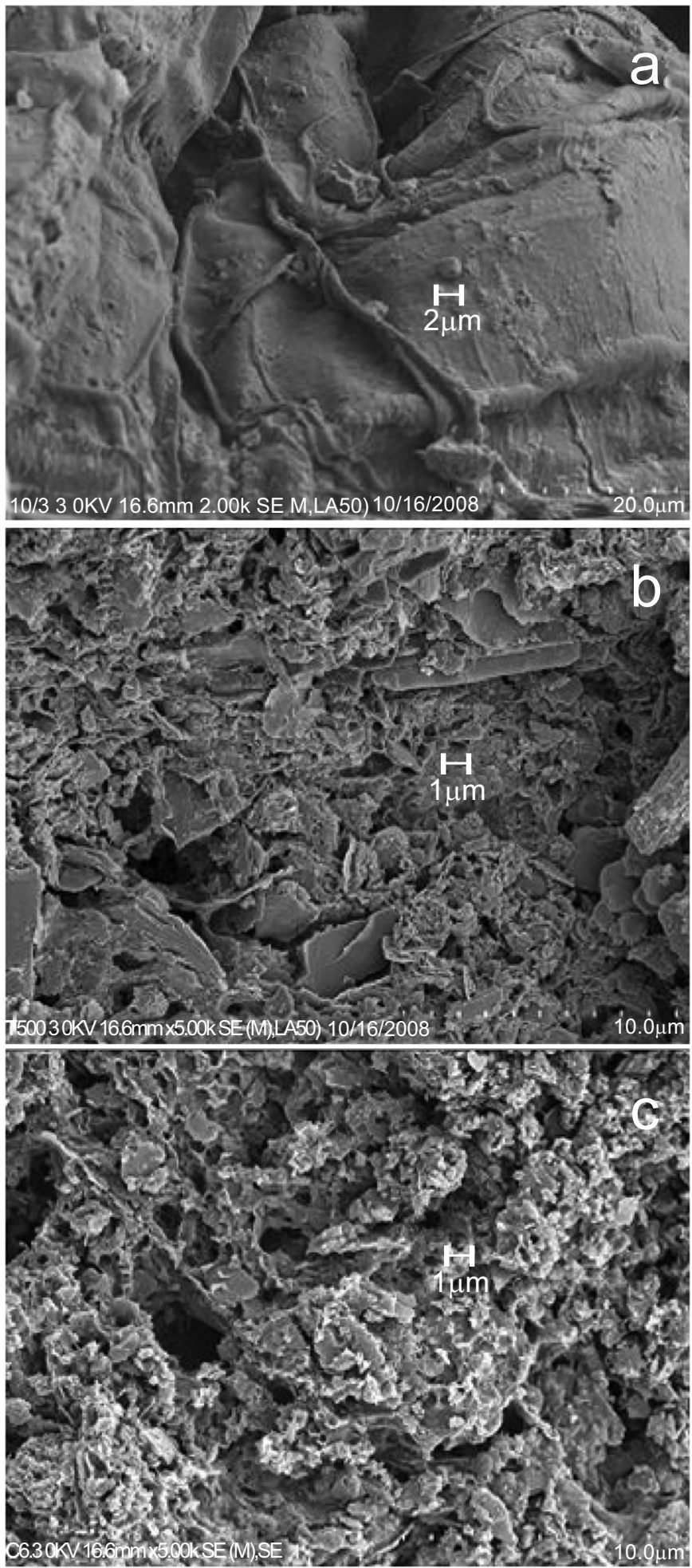

Fig. (3). SEM photograph of dried sludge (a), carbonized sludge (b) and activated carbon (c).

Fig. (4) shows the carbonization characteristics of sludge by particle size as the results obtained by changing particle sizes up to $0.25-3 \mathrm{~mm}$. In this case, fixed conditions were set at $10 \%, 600^{\circ} \mathrm{C}$, and 60 minutes in water content, carboni- zation temperature and carbonization time. The optimum condition was set at $0.25-5 \mathrm{~mm}$ at particle size change studies. In this case, iodine adsorptivity turned out to be $120.6 \mathrm{mg} / \mathrm{g}$. The particle size was in reverse proportion to the iodine adsorptivity. This is because particle size was in reverse proportion to the specific surface area that make carbonization reaction possible.

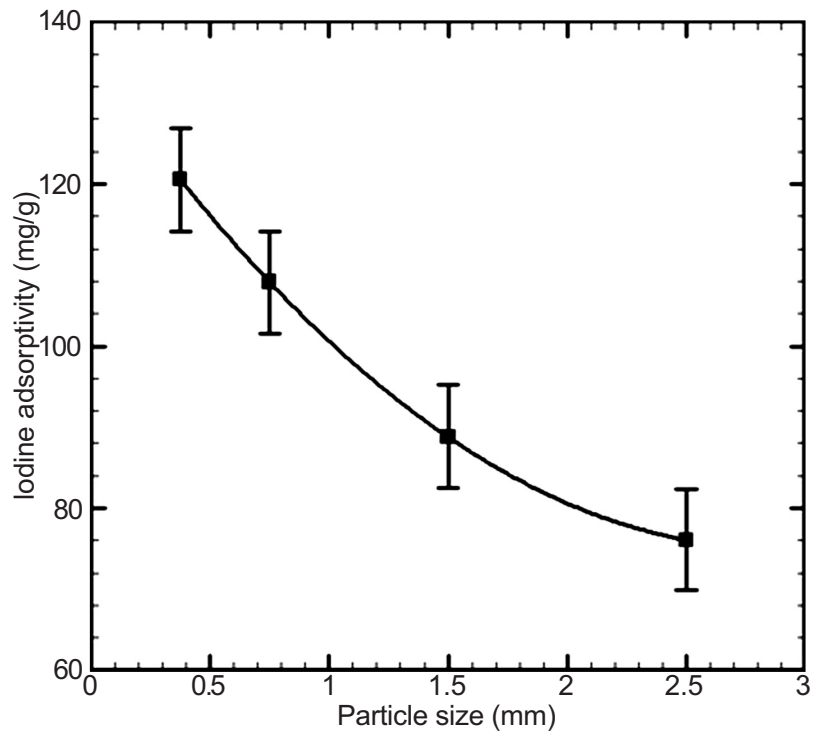

\begin{tabular}{|c|c|c|c|c|}
\hline Particle size $(\mathrm{mm})$ & $0.25 \sim 0.5$ & $0.5 \sim 1$ & $1 \sim 2$ & $2 \sim 3$ \\
\hline Number of repetitions & 4 & 4 & 3 & 3 \\
\hline
\end{tabular}

Fig. (4). Effect of particle size on iodine adsorptivity.

Fig. (5) shows the carbonization characteristics by the changes in water content. The study was conducted by fixing the particle sizes selected in Fig. (4) at $0.25-0.5 \mathrm{~mm}$ and then

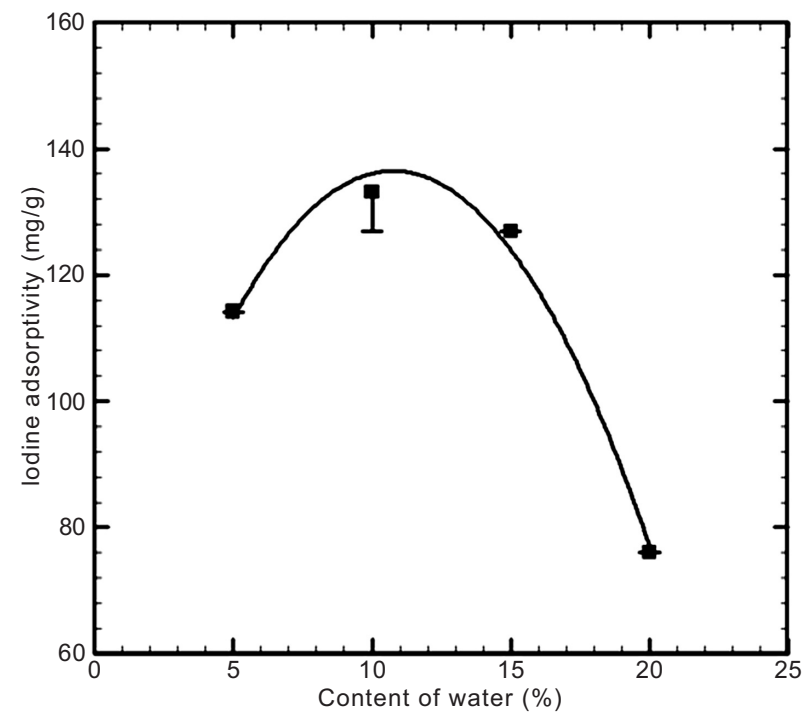

\begin{tabular}{|c|c|c|c|c|}
\hline Content of water $(\%)$ & 5 & 10 & 15 & 20 \\
\hline Number of repetitions & 2 & 2 & 2 & 2 \\
\hline
\end{tabular}

Fig. (5). Effect of content of water on iodine adsorptivity. 
changing water contents in the range 5-20\%. As a result, $10 \%$ water content was selected as an optimum condition, with iodine adsorptivity set at $133.2 \mathrm{mg} / \mathrm{g}$ as the highest value. This was because water partially worked as an activating agent in the process of carbonization. However, carbonization reaction is influenced by the latent heat of vaporization at the water content above $10 \%$.

Fig. (6) shows the changes of carbonization characteristics according to carbonization temperature. As a result, 600 ${ }^{\circ} \mathrm{C}$ turned out to be an optimum condition, with iodine adsorptivity set at $161.8 \mathrm{mg} / \mathrm{g}$ as the highest value. This was not only because the main reaction of carbonization in eqs. (4), (5) was actively (produced)proceeded with the increase of carbonization temperature, but also because sewage sludge showed the reduction of adsorption characteristics due to the contraction and sintering of char at temperatures above $600{ }^{\circ} \mathrm{C}$ [14]:

$$
\mathrm{C}_{\alpha} \mathrm{H}_{\beta} \text { (organic substance) } \rightarrow \gamma \mathrm{CH}_{4}+\delta \mathrm{H}_{2}+\mathrm{C}(\text { char })
$$

$\mathrm{CH}_{4}+\mathrm{H}_{2} \mathrm{O} \rightarrow \mathrm{CO}+3 \mathrm{H}_{2}$

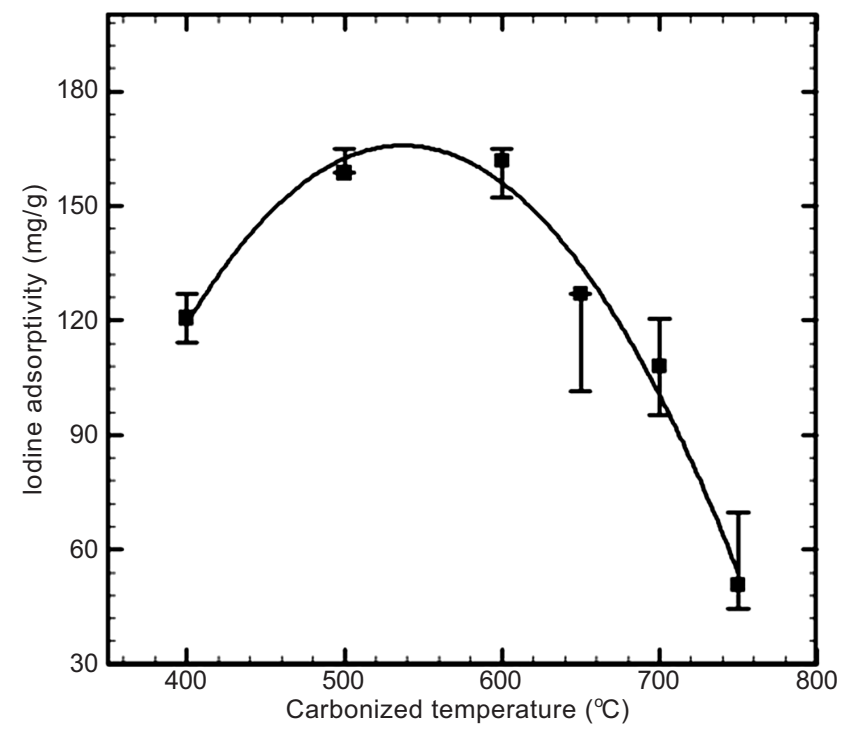

\begin{tabular}{|c|c|c|c|c|c|c|}
\hline Carbonized temperature $\left({ }^{\circ} \mathrm{C}\right)$ & 400 & 500 & 600 & 650 & 700 & 750 \\
\hline Number of repetitions & 2 & 2 & 2 & 2 & 3 & 3 \\
\hline
\end{tabular}

Fig. (6). Effect of carbonized temperature on iodine adsorptivity.

Fig. (7) shows the changes of carbonization characteristics according to carbonization time. In this regard, 60 minutes was selected as an optimum condition, with iodine adsorptivity set at $161.8 \mathrm{mg} / \mathrm{g}$ as the highest value. However, if reaction was made for more than 60 minutes, pores were sintered with the increase in thermal exposure time, thus decreasing adsorption characteristics.

\section{Steam Activation}

\section{II-1. Standard Conditions}

This study is aimed to grasp the adsorption characteristics and optimum conditions of activation by acid-washing and water-washing the carbonized sludge under optimum conditions with the $3 \mathrm{~N}$ hydrochloric acid and then perform- ing repetitive variable studies. In this case, acid-washing causes an activation reaction by removing the volatile and inorganic substances such as tar and oil, which are left after carbonization, and making steam actively infiltrate into pores. As shown in Table $\mathbf{4}$, optimum activation conditions turned out to be $30 \mathrm{ml} / \mathrm{min}, 500{ }^{\circ} \mathrm{C}$ and 60 minutes in steam injection amount, activation temperature and activation time respectively. In this case, iodine adsorptivity and adsorbent yield were $228.4 \mathrm{mg} / \mathrm{g}$, and $77.23 \%$ respectively. Activated carbon showed an intermediate form between Type I and Type II in the nitrogen adsorption isotherm of Fig. (2). In addition, the activated carbon manufactured through activation showed the development of pores in all the areas from micropore to macropore, compared to carbonized sludge. This corresponds to the fact that iodine adsorptivity and specific surface area in Table 3 increased from $161.8 \mathrm{mg} / \mathrm{g}$ and $62.31 \mathrm{~m}^{2} / \mathrm{g}$ to $228.4 \mathrm{mg} / \mathrm{g}$ and $288.28 \mathrm{~m}^{2} / \mathrm{g}$ in carbonized sludge and activated carbon respectively. In addition, Fig. (3c) shows that the formation of porosity developed on the

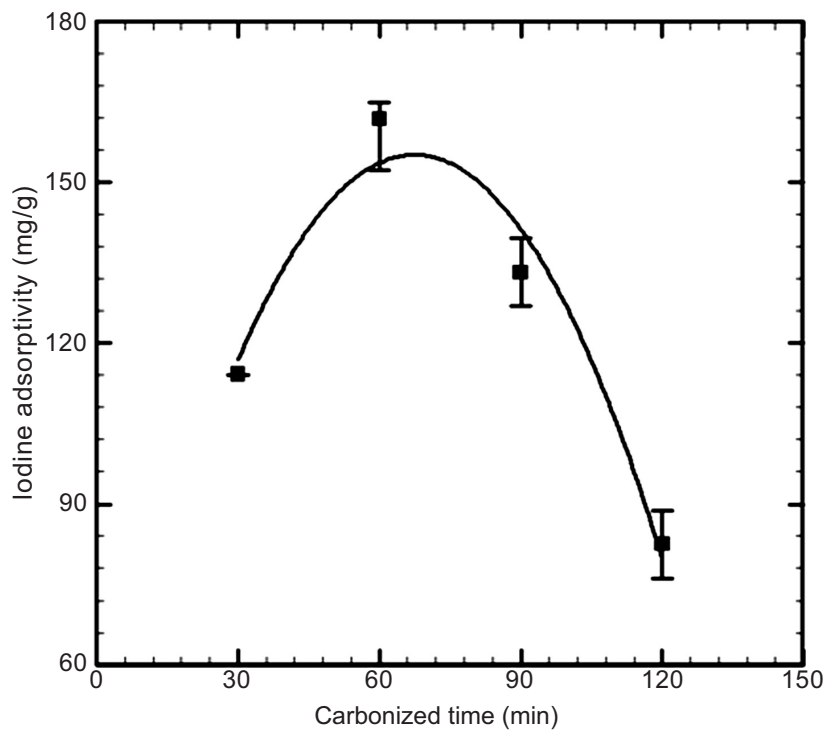

\begin{tabular}{|l|c|c|c|c|}
\hline Carbonized time (min) & 30 & 60 & 90 & 120 \\
\hline Number of repetitions & 2 & 2 & 2 & 2 \\
\hline
\end{tabular}

Fig. (7). Effect of carbonized time on iodine adsorptivity.

Table 4. Standard Conditions and Experimental Data of Activated Carbon

\begin{tabular}{|c|c|c|c|}
\hline \multicolumn{3}{|r|}{ Item } & Value \\
\hline \multirow{5}{*}{$\begin{array}{l}\text { Activated } \\
\text { carbon }\end{array}$} & \multirow{3}{*}{$\begin{array}{l}\text { Standard } \\
\text { condition }\end{array}$} & Steam injection amount $(\mathrm{ml} / \mathrm{min})$ & 30 \\
\hline & & Temperature $\left({ }^{\circ} \mathrm{C}\right)$ & 500 \\
\hline & & Time $(\min )$ & 60 \\
\hline & \multirow{2}{*}{$\begin{array}{c}\text { Experimental } \\
\text { data }\end{array}$} & Iodine adsorptivity (mg/g) & 228.4 \\
\hline & & Adsorbent yield (\%) & 77.23 \\
\hline
\end{tabular}


surface of activated carbon than in the carbonized sludge of Fig. (3b). In particular, specific surface area values calculated with the HK(Horvath-Kawazoe) method in Table $\mathbf{3}$ show that micropore was developed by steam activation. This was also confirmed by the findings in RodriguezReinoso et al. [7].

\section{II-2. Parametric Screening Studies}

Variable studies were performed to grasp the influential factors by steam activation and to select optimum activation conditions. They were proceeded, with steam injection amount, activation temperature and activation time selected as the influential factors of steam activation and changed into $10-50 \mathrm{ml} / \mathrm{min}, 300-850{ }^{\circ} \mathrm{C}$, and $30-120$ minutes respectively.

Fig. (8) shows the iodine adsorptivity and adsorbent yield by steam injection amount in steam activation. In this regard, steam injection amount was changed into $10-70 \mathrm{ml} / \mathrm{min}$, and activation temperature and time were fixed at $500{ }^{\circ} \mathrm{C}$ and 60 minute respectively. As a result, iodine adsorptivity and adsorbent yield turned out to be $222.05 \mathrm{mg} / \mathrm{g}$, the highest value and $92.57 \%$ respectively at the steam injection amount of 30 $\mathrm{ml} / \mathrm{min}$. Under the condition of $30 \mathrm{ml} / \mathrm{min}$, the activation reactions in eqs. (6)-(9) were actively produced. But under the condition above $30 \mathrm{ml} / \mathrm{min}$, the hydrogen molecules generated from the dissolution of steam is adhered to the surface of carbon, thus preventing activation, and excess oxidative gas damages pores, thus lowering adsorption capacity [15]:

$$
\begin{aligned}
& \mathrm{C}+\mathrm{H}_{2} \mathrm{O} \rightarrow \mathrm{C}\left(\mathrm{H}_{2} \mathrm{O}\right) \\
& \mathrm{C}\left(\mathrm{H}_{2} \mathrm{O}\right) \rightarrow \mathrm{H}_{2}+\mathrm{CO} \\
& \mathrm{C}(\mathrm{O}) \rightarrow \mathrm{CO} \\
& \mathrm{C}+\mathrm{H}_{2} \mathrm{O} \rightarrow \mathrm{CO}+\mathrm{H}_{2}
\end{aligned}
$$

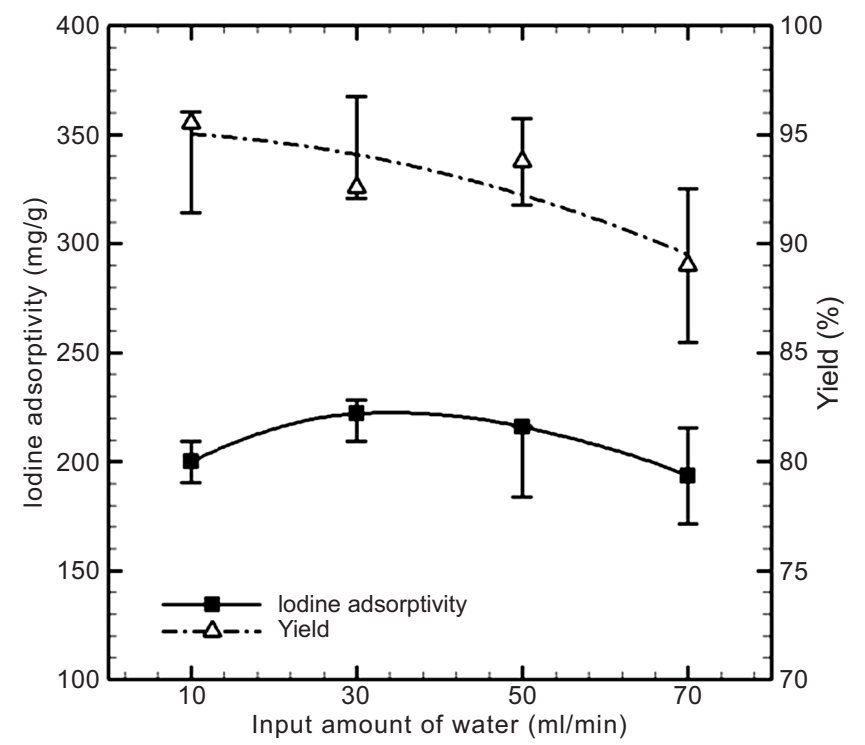

\begin{tabular}{|c|c|c|c|c|}
\hline Input amount of water (m1/min) & 10 & 30 & 50 & 70 \\
\hline Number of repetitions & 4 & 3 & 4 & 3 \\
\hline
\end{tabular}

Fig. (8). Effect of input amount of water on iodine adsorptivity and yield.
The adsorbent yield was presented almost uniformly regardless of steam injection amount.

Fig. (9) shows the temperature-specific iodine adsorptivity and adsorbent yield obtained by changing activation temperature into $300-850{ }^{\circ} \mathrm{C}$ and then performing steam activation. As a result, optimum temperature and adsorbent yield turned out to be $500{ }^{\circ} \mathrm{C}$ and $74.33 \%$ respectively. Such optimum activation temperature was selected because the highest value was seen at $750{ }^{\circ} \mathrm{C}$ at the time of analyzing iodine adsorptivity, but because BET specific surface area was the highest $\left(288.28 \mathrm{~m}^{2} / \mathrm{g}\right)$ at $500{ }^{\circ} \mathrm{C}$ at the time of analyzing nitrogen adsorption in accordance with the changes of activation temperature in Table $\mathbf{5}$. The decrease in adsorptivity is caused by the solution of intermediate products by the emission of the second volatile matter [16], at the activation temperature above $500{ }^{\circ} \mathrm{C}$, but by the contraction and sintering by high activation temperature, at the activation temperature above $750{ }^{\circ} \mathrm{C}$. In addition, activation temperature has maximum influence on adsorbent yield.

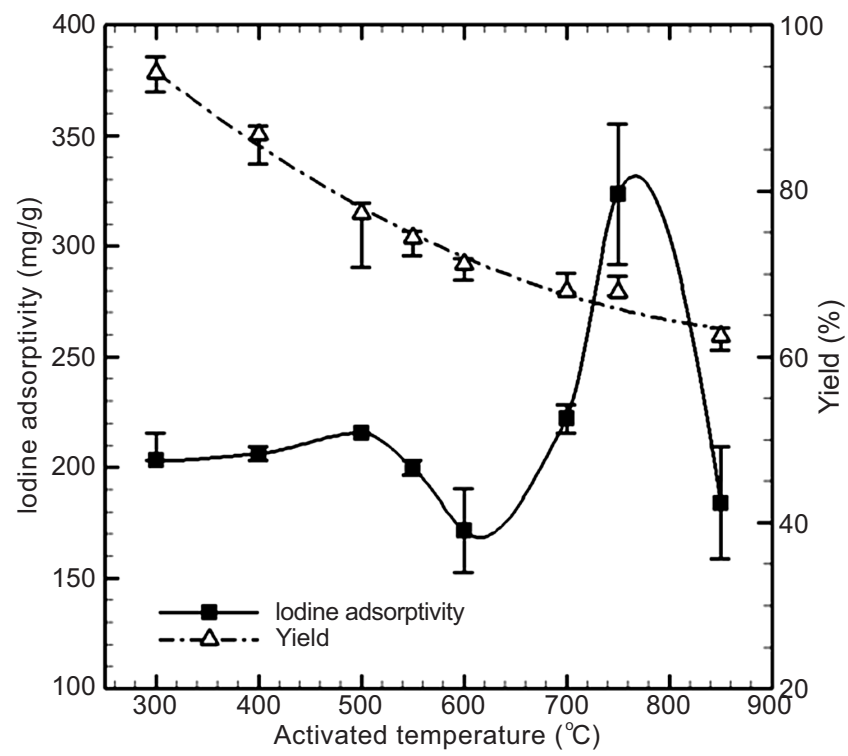

\begin{tabular}{|c|c|c|c|c|c|c|c|c|}
\hline $\begin{array}{c}\text { Activated } \\
\text { temperature }\left({ }^{\circ} \mathrm{C}\right)\end{array}$ & 300 & 400 & 500 & 550 & 600 & 700 & 750 & 850 \\
\hline $\begin{array}{c}\text { Number of } \\
\text { repetitions }\end{array}$ & 2 & 2 & 2 & 2 & 2 & 2 & 2 & 2 \\
\hline
\end{tabular}

Fig. (9). Effect of activated temperature on iodine adsorptivity and yield.

Table 5. Effect of Activated Temperature on Specific Surface Area

\begin{tabular}{|c|c|c|c|c|c|c|}
\hline $\begin{array}{c}\text { Activated } \\
\text { Temperature }\left({ }^{\circ} \mathbf{C}\right)\end{array}$ & $\mathbf{3 0 0}$ & $\mathbf{4 0 0}$ & $\mathbf{5 0 0}$ & $\mathbf{6 0 0}$ & $\mathbf{7 0 0}$ & $\mathbf{8 0 0}$ \\
\hline \hline $\begin{array}{c}\text { BET specific } \\
\text { Surface Area }\left(\mathrm{m}^{2} / \mathrm{g}\right)\end{array}$ & 224.86 & 235.54 & 288.28 & 237.64 & 206.55 & 155.40 \\
\hline
\end{tabular}


Fig. (10) shows the adsorption characteristics of activated carbon by activation time which were obtained from the studies performed in accordance with the changes from 30 to 120 minutes. As a result, activation time turned out to be optimal at 60 minutes. In this case, iodine adsorptivity and adsorbent yield rate turned out $228.4 \mathrm{mg} / \mathrm{g}$ and $77.23 \%$ respectively. In case of activation process above 60 minutes, the increase in thermal contact time causes the contraction of char, lowering adsorption capacity.

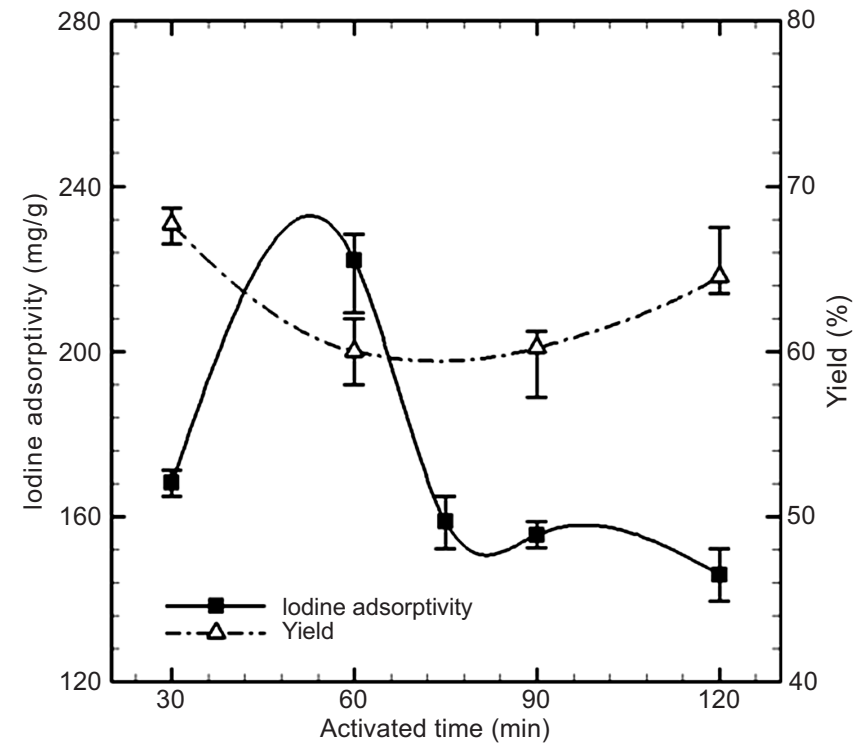

\begin{tabular}{|c|c|c|c|c|}
\hline Activated time (ml/min) & 30 & 60 & 90 & 120 \\
\hline Number of repetitions & 2 & 3 & 3 & 3 \\
\hline
\end{tabular}

Fig. (10). Effect of activated time on iodine adsorptivity and yield.

\section{DISCUSSION AND CONCLUSION}

This study selected the influential variables of carbonization and steam activation, and drew out the conditions for optimum carbonization and activation through variable studies. In addition, the study grasped nitrogen adsorption as well as specific surface area, pore volume, mean pore diameter and pore development with a SEM. The results are as follows.

The carbonization of sewage sludge did not give satisfactory results in terms of adorptivity and pore development, but steam activation enabled to confirm that not only micropores but macropores were considerably developed in all sections and that adsorptivity was improved. In particular, micropores were mostly developed by steam activation. The comparison of the results with those in Lee at al. [17] showed differences in optimum activation conditions, i.e. steam injection amount, activation temperature and activation time. In addition, different tendencies were seen in the variable studies for influential variables.

The following are the carbonization and stream activation adsorption characteristics of sewage sludge by variable studies.
1) The carbonization of sewage sludge showed that the particle size was inversely proportional to adsorption capacity and the water content of $10 \%$ showed the highest iodine adsorptivity. This was because the water in carbonized samples helped the formation of pores by partially working as an activator during the carbonization process

2) Carbonization temperature and time had the best adsorption capacity at $600{ }^{\circ} \mathrm{C}$ and 60 minutes respectively. However, adsorption characteristics were decreased by the contraction and sintering of pores by heat, under the conditions above such temperature and time.

3) In case of steam activation, pores were well formed by appropriate partial oxidation at the steam injection amount of $30 \mathrm{ml} / \mathrm{min}$, but the formation of pores was damaged by the hydrogen molecules and excess oxidative gas generated by the dissolution of steam.

4) Unlike iodine adsorptivity, activation temperature constituted optimum conditions at $500{ }^{\circ} \mathrm{C}$ that generated the highest specific surface area calculated by nitrogen adsorption. At the activation temperature above $500{ }^{\circ} \mathrm{C}$, adsorption capacity was lowered by the influences of the solution according to the formation of the second products and by the contraction and sintering according to high heat.

5) If activation time exceeds 60 minutes, iodine adsorptivity was decreased, as pores are sintered with the increase in thermal exposure time.

\section{REFERENCES}

[1] Comprehensive Countermeasures of Sewage Sludge Management. Ministry of Environment of Korea, Editorial Board of Advanced Environmental Technology 2007, Vol. 15(12), pp. 1-3.

[2] Choung, Y. H.; Cho, K. C.; Choi, W. J.; Kim, S. G.; Han, Y. S.; Oh, K. J. Attrition of sewage sludge and sludge-based char in a fluidized bed reactor. Korean J. Chem. Eng., 2007, 24(4), 660-663.

[3] Goldsteim, N. Biocycle survey sewage sludge composting as a medium amendment for chrysanthemum culture. J. Am. Soc. Hortic. Sci., 1985, 100, 213-216.

[4] Khalili, N. R.; Campbell, M.; Sandi , G.; Golas, J. Production of micro- and mesoporous activated carbon from paper mill sludge. Carbon, 2000, 38(14), 1905-1915.

[5] Jung, D. H.; Chun, Y. N. Study on the design of attached revolution body horizontal rotary kiln dryer and the optimum operational conditions. J. Korean Ind. Eng. Chem., 2007, 18(6), 575-579.

[6] Chiang, P. C.; You, J. H. Use of sewage sludge for manufacturing adsorbents. J. Chem. Eng., 1987, 65, 922-928.

[7] Rodriguez-Reinoso, F.; Molina-Sabio, M.; Gonzalez, M. T. The use of steam and $\mathrm{CO}_{2}$ as activating agents in the preparation of activated carbons. Carbon, 1995, 33(1), 15-23.

[8] Hwang, H. R.; Choi, W. J.; Kim, T. J.; Kim, J. S.; Oh, K. J. The preparation of an adsorbent from mixtures of sewage sludge and coal-tar pitch using an alkaline hydroxide activation agent. J. Anal. Appl. Pyrolysis, 2008, 83, 20-226.

[9] Bagreev, A.; Bandosz, J. T.; Locke, D. C. Pore structure and surface chemistry of adsorbents obtained by pyrolysis of sewage sludge-derived fertilizer. Carbon, 2001, 39, 1971-1979.

[10] Sing, K. S. W. Reporting physisorption data for gas solid systems with special reference to the determination of surface area and porosity. Pure Appl. Chem., 1982, 54(11), 2201-2218.

[11] Barrett, E. P.; Joyner, L. G.; Halenda, P. P. The determination of pore volume and area distributions in porous substances. J. Am. Chem. Soc., 1951, 73, 373-379.

[12] Horvath, G.; Kawazoe, K. Method for the calculation of effective pore size distribution in molecular sieve carbon. J. Chem. Eng. Jpn., 1983, 16(6), 470-475.

[13] Maiboom, A.; Tauzia, X.; Hetet, J. F. Experimental study of various effects of exhaust gas recirculation (EGR) on combustion 
and emissions of an automotive direct injection diesel engine. Energy, 2008, 33, 22-34.

[14] Ahmadpour, A.; Do, D. D. The preparation of active carbons from coal by chemical and physical activation. Carbon, 1996, 34(4), 471-479.

[15] Kang, H. Y. Adsorption characteristics of activated carbon prepared from wasted biological sludge. Thesis University Chonbuk, 2000, pp. 56-59.
[16] Lu, G. Q.; Low, J. C. F.; Liu, C. Y.; Lua, A. C. Surface area development of sewage sludge during pyrolysis. Fuel, 1995, 74(3), 344348.

[17] Lee, Y. D.; Kang, H. Y. The preparation of activated carbons from waste sludge by physical and chemical activation. J. Korean Solid Waste Eng. Soc., 2000, 17(5), 562-574.

Received: February 2, 2009

Revised: February 25, 2009

Accepted: March 9, 2009

(C) Jung and Chun; Licensee Bentham Open.

This is an open access article licensed under the terms of the Creative Commons Attribution Non-Commercial License (http://creativecommons.org/licenses/ by-nc/3.0/) which permits unrestricted, non-commercial use, distribution and reproduction in any medium, provided the work is properly cited. 